\title{
Dibromopinocembrin and Dibromopinostrobin Are Potential Anti-Dengue Leads with Mild Animal Toxicity
}

\author{
Siwaporn Boonyasuppayakorn ${ }^{1, *(1)}$, Thanaphon Saelee ${ }^{1}$, Peerapat Visitchanakun ${ }^{2,3}$, \\ Asada Leelahavanichkul ${ }^{3}$, Kowit Hengphasatporn ${ }^{4}$, Yasuteru Shigeta ${ }^{4}$, \\ Thao Nguyen Thanh Huynh ${ }^{5}$, Justin Jang Hann Chu ${ }^{6}$, Thanyada Rungrotmongkol ${ }^{7,8}$ and \\ Warinthorn Chavasiri ${ }^{5}$ \\ 1 Applied Medical Virology Research Unit, Department of Microbiology, Faculty of Medicine, \\ Chulalongkorn University, Bangkok 10330, Thailand; thanaphon.saelee@gmail.com \\ 2 Interdisciplinary Program in Microbiology, Graduate School, Chulalongkorn University, Bangkok 10330, \\ Thailand; peerapat.visitchanakun@gmail.com \\ 3 Translational Research in Inflammation and Immunology Research Unit, Department of Microbiology, \\ Faculty of Medicine, Chulalongkorn University, Bangkok 10330, Thailand; aleelahavanit@gmail.com \\ 4 Center for Computational Sciences, University of Tsukuba, 1-1-1 Tennodai, Tsukuba, Ibaraki 305-8577, Japan; \\ heng.kowit@gmail.com (K.H.); shigeta@ccs.tsukuba.ac.jp (Y.S.) \\ 5 Center of Excellence in Natural Products Chemistry, Department of Chemistry, Faculty of Science, \\ Chulalongkorn University, Bangkok 10330, Thailand; thao.huynhthanh94@gmail.com (T.N.T.H.); \\ warinthorn.c@chula.ac.th (W.C.) \\ 6 Laboratory of Molecular RNA Virology and Antiviral Strategies, Department of Microbiology and \\ Immunology, Yong Loo Lin School of Medicine, National University of Singapore, Singapore 117545, \\ Singapore; miccjh@nus.edu.sg \\ 7 Program in Bioinformatics and Computational Biology, Graduate School, Chulalongkorn University, \\ Bangkok 10330, Thailand; thanyada.r@chula.ac.th \\ 8 Biocatalyst and Environmental Biotechnology Research Unit, Department of Biochemistry, Faculty of \\ Science, Chulalongkorn University, Bangkok 10330, Thailand \\ * Correspondence: siwaporn.b@chula.ac.th
}

Academic Editors: Mai Antonello, Justin Jang Hann Chu and Chee Keng Mok

Received: 4 August 2020; Accepted: 9 September 2020; Published: 11 September 2020

\begin{abstract}
Dengue infection is one of the most deleterious public health concerns for two-billion world population being at risk. Plasma leakage, hemorrhage, and shock in severe cases were caused by immunological derangement from secondary heterotypic infection. Flavanone, commonly found in medicinal plants, previously showed potential as anti-dengue inhibitors for its direct antiviral effects and suppressing the pro-inflammatory cytokine from dengue immunopathogenesis. Here, we chemically modified flavanones, pinocembrin and pinostrobin, by halogenation and characterized them as potential dengue 2 inhibitors and performed toxicity tests in human-derived cells and in vivo animal model. Dibromopinocembrin and dibromopinostrobin inhibited dengue serotype 2 at the $\mathrm{EC}_{50} \mathrm{~s}$ of $2.0640 \pm 0.7537$ and $5.8567 \pm 0.5074 \mu \mathrm{M}$ with at the $\mathrm{CC}_{50} \mathrm{~s}$ of $67.2082 \pm 0.9731$ and $>100 \mu \mathrm{M}$, respectively. Both of the compounds also showed minimal toxicity against adult C57BL/6 mice assessed by ALT and Cr levels in day one, three, and eight post-intravenous administration. Computational studies suggested the potential target be likely the NS5 methyltransferase at SAM-binding pocket. Taken together, these two brominated flavanones are potential leads for further drug discovery investigation.
\end{abstract}

Keywords: dengue virus; flavanone; flavonoid; antiviral drug; dengue methyltransferase; drug discovery; pinocembrin; pinostrobin 


\section{Introduction}

Mosquito-borne viruses, especially the four serotypes of dengue viruses, are health burden worldwide with 4.2 million case reports in 2019 [1]. Moreover, reported deaths increase from 960 to 4032 during 2000-15 [1]. Severe manifestations of dengue, such as plasma leakage, hemorrhage, multiple organ failure, and hypovolemic shock, are caused by a secondary heterotypic infection that leads to misled immunological response towards the previous serotype [2]. Moreover, evidence suggested that the viral load is higher in severe cases [3] because of increasing viral replication from partially neutralized antibody-mediated opsonization into a macrophage. Therefore, inhibiting viral replication could potentially alleviate the clinical severity. However, no specific drug is currently available for the treatment of severe dengue.

The flaviviral replication starts with a specific binding between viral envelope (E) protein and cellular receptors [4]. This virus entered the cells via clathrin-mediated endocytosis [5] and escaped by fusion under acidic environment [6]. The positive-sense RNA genome also serves as an mRNA for translation en bloc to viral proteins utilized in subsequent viral replication, the termination of host protein translation, and suppression of interferon signaling. The virus particle is assembled in the endoplasmic reticulum [7] and travels through Golgi complex for maturation by furin cleavage. The viral particle is released by budding out of the infected cells [8]. Potential drugs were designed and developed to interfere with those steps of viral replication or to target the pathological activation of pro-inflammatory cytokines.

Flavonoids were plant-derived secondary metabolites with various biological activities, including antivirals and anti-inflammation. A previous report suggested that halogenation of chrysin (5,7-dihydroxyflavone) enhances the efficacy against dengue and Zika viruses [9] in the cell-based system. However, two halogenated chrysins exhibited limited aqueous solubility at the administrative dose, preventing further animal toxicity investigation. To overcome the challenge, a flavanone substrate with higher solubility was considered as a replacement. Moreover, pinocembrin (5,7-dihydroxyflavanone), was previously reported as a potential inhibitor of dengue [10,11] and Zika viruses [12] with possible targets at viral NS2B-3 protease [12-14]. Moreover, anti-flaviviral inhibition was also reported in other flavanones, such as pinostrobin, naringenin, hesperitin, and their derivatives. In this study, we hypothesized whether halogenation of selected potential flavanones, pinocembrin and pinostrobin, would enhance antiviral efficiency similar to those of the flavones, and increase aqueous solubility to be eligible for toxicity studies in cell-based and animal model.

\section{Results}

\subsection{Compound Syntheses and Identification}

\subsubsection{Synthetic Protocol}

The bromination and iodination of pinostrobin (TH019) and pinocembrin (TH022) were adapted from the protocol previously described [15] (Figure 1). Following the reactions, 6,8-dibromopinostrobin (TH002), 6,8-dibromopinocembrin (TH011), 6,8-diiodopinocembrin (TH012), and 6-iodopinostrobin (TH018) were isolated using silica gel chromatography, yielding 96\%, 93\%, 73\%, and 10\%, respectively. 


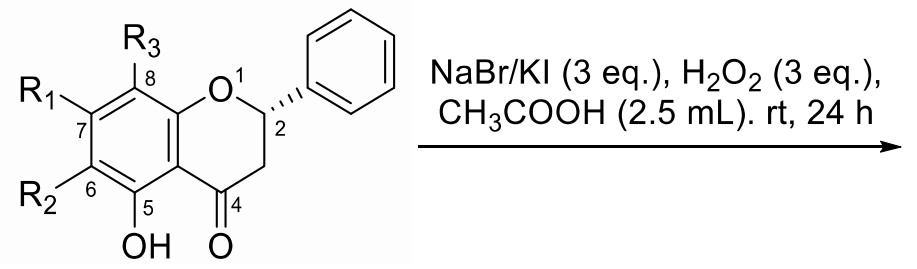<smiles>[R]c1c([R])c(O)c2c(c1[R])O[C@H](c1ccccc1)CC2=O</smiles>

$\mathbf{R}_{1}=\mathrm{OH}, \mathrm{R}_{2}, \mathrm{R}_{3}=\mathrm{H}$ : Pinocembrin (TH022) $\mathrm{R}_{1}=\mathrm{OCH}_{3}, \mathrm{R}_{2}, \mathrm{R}_{3}=\mathrm{H}$ : Pinostrobin (TH019)

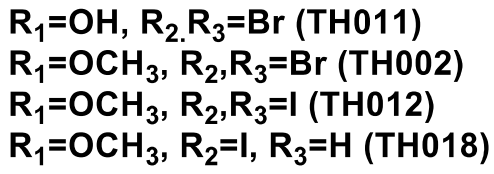

Figure 1. Chemical structures of pinocembrins; TH011 and TH022, and pinostrobins; TH002, TH012, TH018, and TH019, and the halogenation scheme.

\subsubsection{Identification by NMR}

The two halogen atoms of TH011, TH002, and TH012 were identified by the loss of two proton signals at 6-, and 8-positions at $\delta_{\mathrm{H}} 6.07$ and $5.94 \mathrm{ppm}$ of pinocembrin (TH022) and pinostrobin (TH019), respectively (Supplementary Figures S1-S3). Furthermore, an addition of two halide atoms created a large shift of chelated hydroxyl proton at position 5 identified as a characteristic signal of the spectra. Similarly, 6-iodopinostrobin (TH018) (Supplementary Figure S4) was recognized by the loss of one proton signal at 6-position and shared the similar characteristic signal of a hydroxyl proton shift at position 5 .

\subsection{Efficacies and Cytotoxicity of Pinocembrin and Pinostrobin Derivatives}

Halogenated pinocembrin and pinostrobin were tested against dengue virus serotype 2 (DENV2), New Guinea C strain in LLC/MK2 cells (Table 1). Cytotoxicities of the compounds were also assessed (Tables 1 and 2). The selectivity index (SI) is a ratio of $\mathrm{CC}_{50}$ and $\mathrm{EC}_{50}$ indicating the safety range of the particular compound to effectively inhibit the virus replication without being cytotoxic to the particular cell line. The results showed that all halogenated derivatives were more potent than their original compounds. The most potent compound was 6,8-dibromopinocembrin (TH011) with an effective concentration $\left(\mathrm{EC}_{50}\right)$ of $2.0640 \pm 0.7537 \mu \mathrm{M}$ and a SI of 32.5621. Additionally, TH011 consistently inhibited another DENV2 strain, 16681, in Huh-7 cells at an EC $_{50}$ of $4.5936 \pm 1.8520 \mu \mathrm{M}$ and a SI of 10.5201. The Huh-7 CC $_{50}$ was $48.3277 \pm 4.1129 \mu \mathrm{M}$ (Table 2). Besides LLC/MK2 and Huh-7, TH011 displayed mild cytotoxicity to THP-1, HepG2, and HEK-293 cell lines (Table 2). The original pinocembrin (TH022) was previously reported as DENV2, and Zika viruses inhibitor with moderate efficacies [16] at the $\mathrm{EC}_{50} \mathrm{~s}$ of 15.45 , and $17.4 \mu \mathrm{M}$, respectively [11,17]. Therefore, we concluded that the dibromopinocembrin (TH011) was more potent than its original compound for DENV2 inhibition.

Table 1. Efficacies and cytotoxicity of pinocembrin and pinostrobin derivatives.

\begin{tabular}{|c|c|c|c|c|}
\hline Compounds & Abbreviation & $\begin{array}{c}\text { DENV2 NGC, (16681) } \\
\text { EC }_{50}(\mu \mathrm{M})\end{array}$ & $\begin{array}{l}\text { LLC/MK2 } \\
\mathrm{CC}_{50}(\mu \mathrm{M})\end{array}$ & $\begin{array}{l}\text { SI NGC, (16681) } \\
\left(\mathrm{CC}_{50} / \mathrm{EC}_{50}\right)\end{array}$ \\
\hline 6,8-dibromopinocembrin & TH011 & $\begin{array}{c}2.0640 \pm 0.7537 \\
(4.5936 \pm 1.8520)\end{array}$ & $67.2082 \pm 0.9731$ & $\begin{array}{c}32.5621 \\
(10.5201)\end{array}$ \\
\hline pinocembrin & TH022 & $15.45^{1}$ & $>100^{1}$ & $>6.47$ \\
\hline 6,8-dibromopinostrobin & TH002 & $\begin{array}{l}5.8567 \pm 0.5074 \\
(3.1933 \pm 1.0971)\end{array}$ & $>100.0000$ & $\begin{array}{l}>17.0745 \\
(23.9342)\end{array}$ \\
\hline 6,8-diiodopinostrobin & TH012 & $2.8000 \pm 1.5544$ & $>10.0000^{2}$ & $>3.5714$ \\
\hline 6-iodopinostrobin & TH018 & $4.1020 \pm 1.8376$ & $>25.0000^{2}$ & $>6.0945$ \\
\hline pinostrobin & TH019 & $10.7567 \pm 1.63$ & $78.7844 \pm 2.9193$ & 7.3242 \\
\hline
\end{tabular}

${ }^{1}$ Srivarangkul et al. 2018 [11] ${ }^{2}$ Insoluble from indicated concentrations. 
Table 2. Cytotoxicities of selected pinocembrin (TH011) and pinostrobin (TH002) derivatives.

\begin{tabular}{ccc}
\hline Cell Lines & TH011 & TH002 \\
& $\mathbf{C C}_{\mathbf{5 0}}(\boldsymbol{\mu M})$ & $\mathbf{C C}_{\mathbf{5 0}}(\boldsymbol{\mu M})$ \\
\hline THP-1 & $>100.0000$ & $51.7889 \pm 2.2990$ \\
HEK-293 & $93.1907 \pm 5.9901$ & $>100.0000$ \\
HepG2 & $>100.0000$ & $49.9188 \pm 2.7029$ \\
Huh-7 & $48.3277 \pm 4.1129$ & $76.4457 \pm 7.2027$ \\
\hline
\end{tabular}

Brominated (TH002) and iodinated (TH012 and TH018) pinostrobins similarly inhibited the DENV2 NGC infectivity at the $\mathrm{EC}_{50}$ around 2.8-5.8 $\mu \mathrm{M}$ (Table 1) exceeding their original compound. However, both iodopinostrobins (TH012 and TH018) were partially dissolved when the concentration exceeded 10 and $25 \mu \mathrm{M}$, respectively, thus limiting their cytotoxic studies. Therefore, bromopinostrobin (TH002) was the most promising candidate, with the SI of 17.0745 (Table 1). TH002 was further analyzed using an alternative system of DENV2 16681-infected Huh-7 cells. The EC 50 and SI results were $3.1933 \pm 1.0971 \mu \mathrm{M}$, and 23.9342, respectively, being relatively similar to those of DENV2 NGCinfected LLC/MK2 cells. Cytotoxicity against various cell lines (Table 2) revealed that TH002 was more toxic to THP1 and HepG2, in contrast to those of TH011. From the efficacies and selectivity results, we concluded that brominated pinocembrin (TH011) and pinostrobin (TH002) were promising candidates for further in vivo toxicity study.

\subsection{In Vivo Toxicity of Pinocembrin and Pinostrobin Derivatives}

Flavonoids generally have low bioavailability due to interactions with digestive enzymes and intestinal microorganisms [18]. Flavanones were metabolized to flavone by CYP2A6 and CYP2A13 in the liver [19] and mainly excreted in urine within 4-8 h [20]. In this study, the compounds were intravenously administered to avoid intestinal interactions; therefore, the toxicity would be observed in nonmetabolized forms of TH011 and TH002. All of the compounds and control were prepared in normal saline solution and administered to C57BL/6 mice at $10 \mathrm{mg} / \mathrm{kg}$, or around 100-200 times higher than the $\mathrm{EC}_{50}$ s previously described. The vehicle control was 10\% dimethylsulfoxide (DMSO) in normal saline solution. General appearance, plasma alanine aminotransferase (ALT), and plasma creatinine (Cr) representing the liver and kidney functions, respectively, were monitored on days one, three, and eight after administrations (Figure 2a,b). Overall, all of the animals were active without any signs of distress or abnormalities suggesting that they were well-tolerated to the drugs. However, ALT levels of the TH002 group were mildly elevated on day 1 and 3, suggesting asymptomatic drug-induced hepatitis. The level was decreased to normal on day 8 suggesting a full recovery. In contrast, $\mathrm{Cr}$ levels did not change in any group, suggesting no detected renal toxicity. Noted that the compounds were challenged to the animals at around 100 times higher than the effective doses.

\subsection{Molecular Target Identification}

Original pinocembrin (TH022) was previously characterized as a ZIKV post-entry inhibitor in a cell-based system [17], and pinostrobin (TH019) was a non-competitively inhibit DENV NS2B-3 protease (pro) activity in vitro [13]. Other flavanone derivatives were previously reported as inhibitors of the viral envelope (E) [11], NS2B-3 pro [14], NS5 polymerase (pol) [21], and cellular factors involving in viral replication [22]. In this section, the halogenated flavanones were characterized for potential molecular targets. Attachment inhibition showed the major targets of both compounds located at post-infection (Figure 3). The compounds did not inhibit DENV envelope-induced fusion under acidic pH (Supplementary Figure S5). Therefore, it was likely that TH011 and TH002 would inhibit the DENV translation and replication similar to the previously characterized pinocembrin (TH022) in ZIKV replicon [17]. 


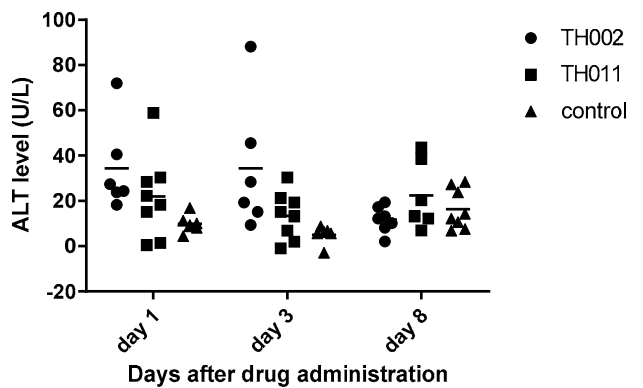

(a)

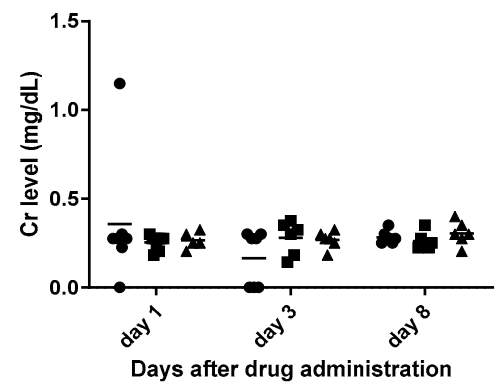

(b)

Figure 2. In vivo toxicity of adult C57BL/6: (a) Alanine aminotransferase level represented the hepatotoxicity; (b) Creatinine level represented the renal toxicity. The 10\% DMSO in normal saline solution was a vehicle control.

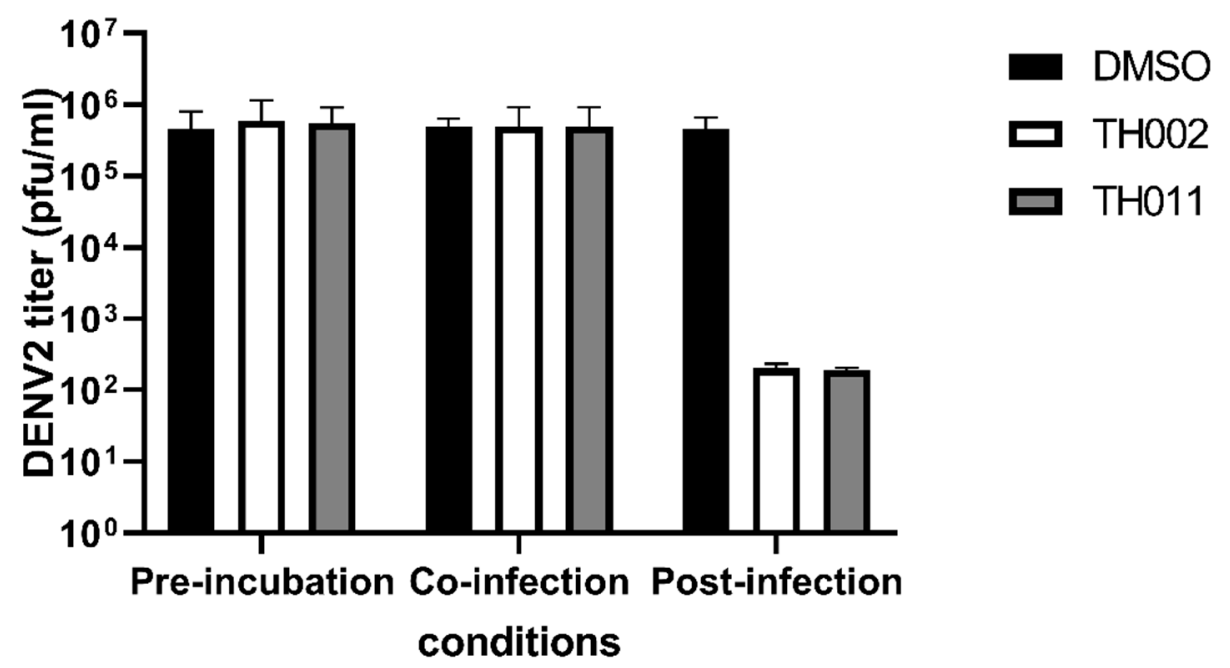

Figure 3. Attachment inhibition assay, DENV2 (16681)-infected Huh-7 cells were treated with $10 \mu \mathrm{M}$ TH002, TH011, or dimethylsulfoxide (DMSO) before, during, or after infection. Three independent experiments were performed to verify the results.

A computational approach was executed to narrow down the possibility of potential targets for our focused compounds becasue hundreds of cellular proteins and interactions are involved in flaviviral replication. The binding affinity of halogenated and original flavanones on DENV2 E, NS2B-3 pro, NS5 methyltransferase (MTase), and NS5 RNA-dependent RNA polymerase (Pol) was predicted and compared with the known inhibitors while using AutoDock VinaXB software in which the halogen bonding parameters were taken into account [23]. The docking results of the four protein targets (Figure 4) showed that the two potent compounds, dibromopinocembrin (TH011) and dibromopinostrobin (TH002), preferentially interacted at the SAM-binding site of NS5 MTase, in which their binding energy of $-9.0 \mathrm{kcal} / \mathrm{mol}$ slightly exceeded that of sinefungin that is commonly used to inhibit the DNA MTases. Although the pinostrobin and one of pinocembrin analogs were previously reported to be active against NS2B-3 pro and NS5 pol, respectively [21,24], none of the halogenated analogs in this study could bind to these targets stronger than their parent compounds TH022 and TH019, as well as the compound 9 [25] and NITD-107 [26], which were protease and NS5 Pol inhibitors, respectively. Besides, the binding affinity of TH011 and TH002 at both kl loop and Y site of the DENV E protein were relatively lower than that of the potent flavanone FN5Y [11] in consistent with no fusion inhibition observed (Supplementary Figure S5). 


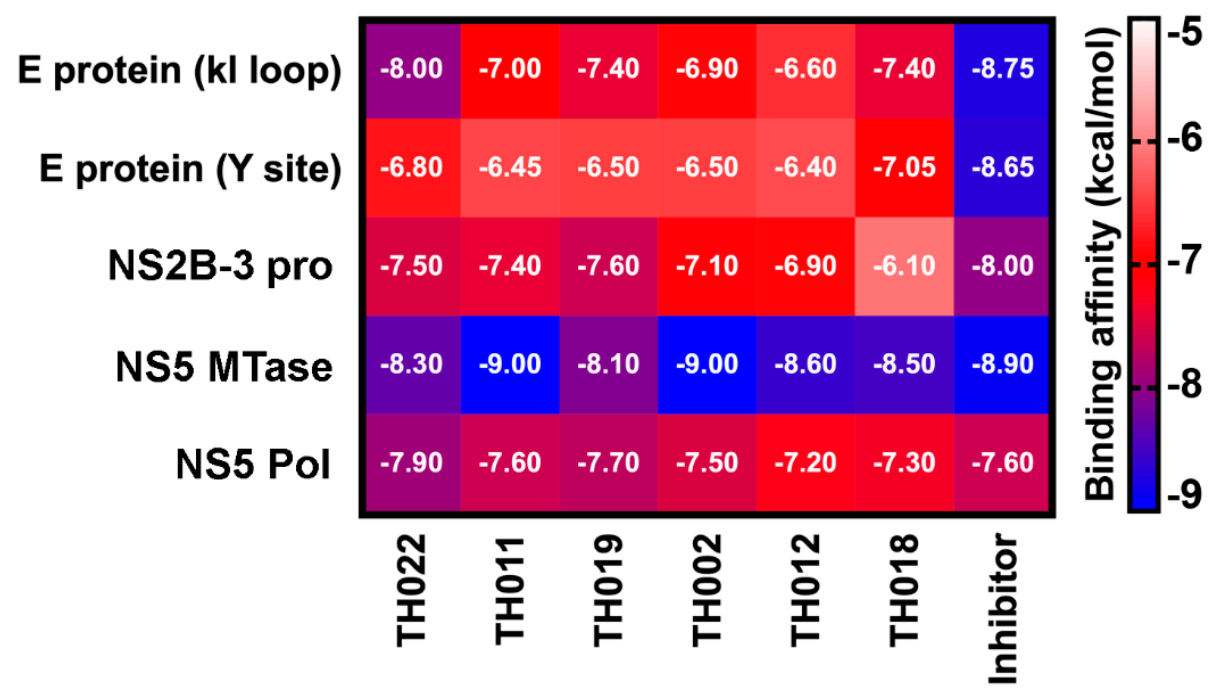

Figure 4. Binding affinity ( $\mathrm{kcal} / \mathrm{mol}$ ) for the studied pinocembrins (TH022 and TH011) and pinostrobins (TH019, TH002, TH012, and TH018) in comparison with the known inhibitors of DENV protein targets: E protein at kl loop and Y site (FN5Y [11]), NS2B-3 pro at allosteric site (compound 9 [25]), NS5 MTase at SAM binding site (Sinefungin [27]), and NS5 Pol at the active site (NITD-107 [26]), predicted by molecular docking method using AutoDock VinaXB.

The molecular dynamics study showed that the dibrominated flavanones; TH011 and TH002, were consistently bound to the SAM-binding site of NS5 MTase throughout the 300-ns (data not shown). To evaluate the stability, binding pattern, and interaction profile of each compound, the per-residue decomposition and binding free energy $\left(\Delta G_{b i n d}\right)$ calculations were performed on the last 100-ns snapshots of ligand-MTase complexes using the Molecular Mechanics-Generalized Born Surface Area method (MM-GBSA) (Figure 5). As a result of the bromine substitutions on the chromone ring of flavanones, the binding affinities of TH011 and TH002 $\left(\Delta G_{b i n d}\right.$ of $-12.50 \pm 1.2$ and $\left.-12.49 \pm 1.2 \mathrm{kcal} / \mathrm{mol}\right)$ were significantly greater than their parent compounds pinocembrin and pinostrobin $(-6.65 \pm 1.6$ and $-0.58 \pm 2.1 \mathrm{kcal} / \mathrm{mol}$ ) (Figure 5a). The phenyl ring of the two dibrominated compounds was stabilized by the $\alpha$ D-helix in particular residues R160, T161, R163 and V164, while only the chromone ring of TH011 orientated at almost the same position as the purine ring of sinefungin intensively interacted with the following residues; G81, T104, K105, H110, V132, and I147. The efficient computational technique based on the FMO-RIMP2/C-PCM method was then carried out to describe electrostatics, polarization, dispersion and charge transfer between the two potent dibrominated flavanones and NS5 MTase. Besides the 12 binding residues that were observed by MM-GBSA calculation, there were two additional key residues G83 and V164 (Figure 5b). At SAM binding site on MTase, the G83 showed the highest contribution to TH011 $(-66.73 \mathrm{kcal} / \mathrm{mol})$ and TH002 $(-69.16 \mathrm{kcal} / \mathrm{mol})$, followed by V164 in TH011 $(-57.33 \mathrm{kcal} / \mathrm{mol})$ and K105 in TH002 $(-57.52 \mathrm{kcal} / \mathrm{mol})$. The essential interaction of TH011 with G83 backbone was from the electrostatic attraction $\left(E_{E S}-57.96 \mathrm{kcal} / \mathrm{mol}\right)$ and the halogen interaction contributed by dispersion $\left(E_{D I}-39.20 \mathrm{kcal} / \mathrm{mol}\right)$ and charge transfer $\left(E_{C T+M I X}-12.65 \mathrm{kcal} / \mathrm{mol}\right)$ to the $\mathrm{Br}^{6}$ on the chromone ring (averaged distance of $3.61 \AA$ in Figure 5c). V164 attributed to the phenyl ring of TH011 by $E_{E S}, E_{D I}$ and $E_{C T+M I X}$ of $\sim-32 \mathrm{kcal} / \mathrm{mol}$ per interaction, while each of the three residues G81, I147 and R163 interplayed for almost $-20 \mathrm{kcal} / \mathrm{mol}$, mainly through $E_{E S}$. Changing from the hydroxyl group in TH011 to the methoxy group in TH002 on the $\mathrm{C}^{7}$ position between the two bromines on the chromone ring led to alternative binding interactions. For example, a decreased contribution in terms of electrostatic interaction and dispersion ( -37.42 and $-34.47 \mathrm{kcal} / \mathrm{mol}$ ) in G83 was compensated by an enhanced charge transfer $(-23.75 \mathrm{kcal} / \mathrm{mol})$. Remarkable higher stabilization was also found at the residues K105 and R160 ( 50 kcal/mol), I147 ( 20 kcal/mol), and R163 ( 10 kcal/mol), whereas the 
residues G81, D131, and V164 repulsed the TH002 binding. Altogether, the finding suggested that the bromine substitution was essential for lead-compound optimization.
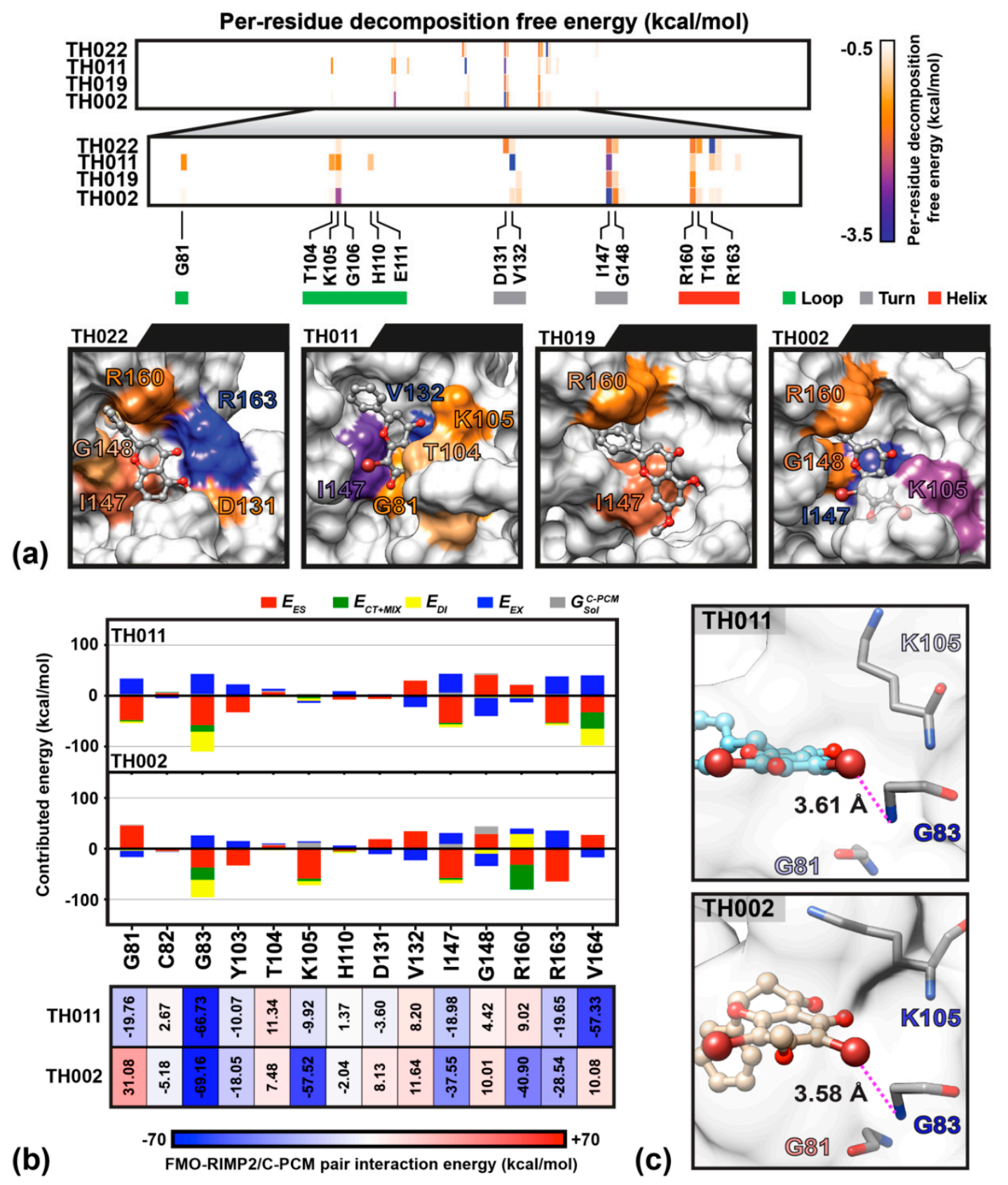

(b)

Figure 5. (a) The important residues and molecular conformation of the four flavanones binding NS5 methyltransferase (MTase) at the SAM pocket obtained from Molecular Mechanics-Generalized Born Surface Area method (MM-GBSA) per-residue decomposition free energy calculation on the MD trajectories during 200-300 ns. The surface color for all systems associated with energy is labeled from -3.5 to $-0.5 \mathrm{kcal} / \mathrm{mol}$ (blue-orange-white). The residues with per-residues decomposition free energy lower than $-1 \mathrm{kcal} / \mathrm{mol}$ are labeled. (b) FMO-RIMP2/C-PCM pair interaction energy (kcal/mol) of surrounding residues with the two potent dibrominated compounds and (c) averaged distance (A) measured between the G83 backbone nitrogen and the $\mathrm{Br}^{6}$ atom of dibrominated flavanones; TH011 and TH002.

From the obtained results, the 6,8-dibrominated flavanone should be kept as the core structure instead of the purine ring of sinefungin, while the chromone ring was optimized by replacing its 
tail, (2R,5R)-2,5-diamino-6-[(3S,4R)-3,4-dihydroxy-5-methyloxolan-2-yl] hexanoic acid, on the $\mathrm{C}^{7}$ atom (Figure 6a). From docking study, the newly designed dibrominated flavanone strongly interacted with the surrounding residues and occupied well in the SAM-binding pocket (Figure 6b) in a correspondence with higher binding affinity $(-10.3 \mathrm{kcal} / \mathrm{mol})$ than either sinefungin $(-8.9 \mathrm{kcal} / \mathrm{mol})$ or TH011 (-9.0 kcal/mol).

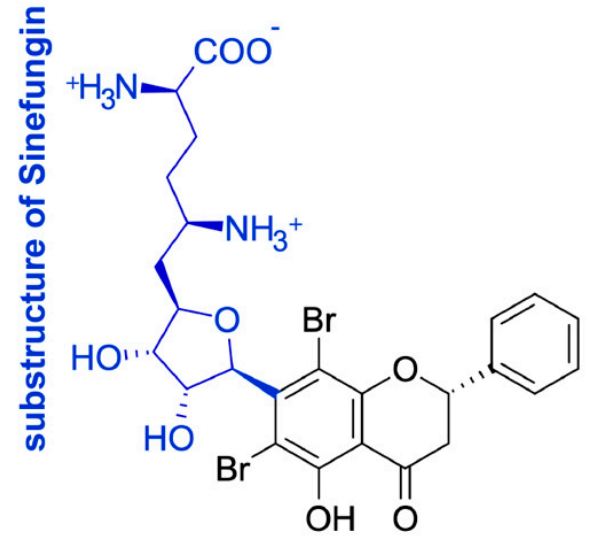

6,8-dibrominated flavanone

(a)

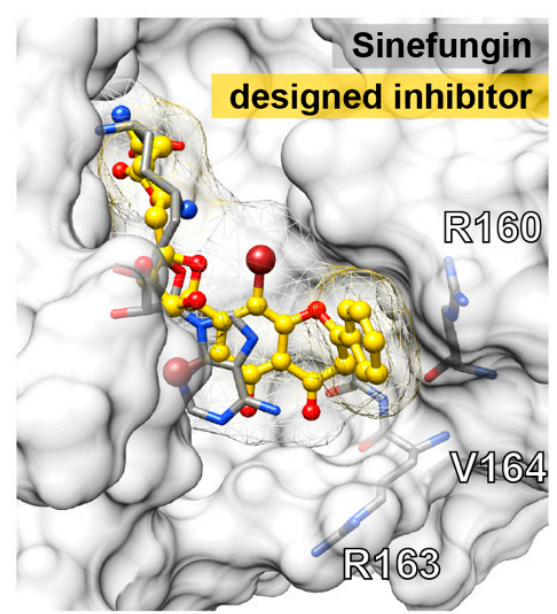

(b)

Figure 6. (a) Two-dimensional (2D) structure of the newly designed compound and (b) its docked conformation in the SAM binding region of dengue NS5 MTase domain compared to the crystal structure of sinefungin in complex with NS5 MTase.

\section{Discussion}

A flavanone structure is a member of flavonoid (C6-C3-C6) with the presence of a chiral center at $\mathrm{C} 2$ and the absence of the C2-C3 double bond [28]. They are plant-derived secondary metabolites originated from chalcones in the flavonoid biosynthetic pathway, and still highly reactive for further structural modifications, such as dehydrogenation, glycosylation, hydroxylation, etc. They are key mediators of various biological processes in plants, such as nitrogen fixation, photosynthesis, energy transfer, and anti-oxidation [15]. Moreover, their activities extended towards anti-cancer, antivirals [10,12,17], and anti-inflammation [29,30]. Generally, flavanones are further metabolized to flavones by the addition of a double bond to C2-C3 of ring C, thus decreasing the aqueous solubility (Supplementary Figure S6) [31].

A previous study reported that halogenated chrysins (6,8-dibromo-, and 6,8-diiodo-5,7-dihydroxyflavone) were potential dengue and Zika inhibitors [9], but the animal toxicity could not be accessed, because of the insolubility issue (data not shown). Halogen atoms have a high electronegativity (EN) property to stably bind to the residues and were hardly metabolized by catalytic enzymes. The question was raised as to whether the halogenated flavanones would also enhance the flaviviral inhibition like halogenated flavones, with an advantage of increasing aqueous solubility. Pinocembrin and pinostrobin were chosen to halogenation for their structural similarities to chrysin. The synthesis was conducted in a one-step process and both bromoflavanones yielded $>90 \%$ by silica gel chromatography. Generally, bromoflavanones (TH002 and TH011) were completely dissolved in culture media, DMSO, and NSS, in contrast, iodoflavanones were re-crystalized after 2-3 days incubation in the cell culture media (data not shown). Despite the solubility issue, all of the halogenated derivatives were similarly effective to inhibit DENV2 NGC at 2.06-5.83 $\mu \mathrm{M}$ (Table 1). Moreover, both TH011 and TH002 were also effectively inhibited DENV2 16,681 at 4.59 and $3.19 \mu \mathrm{M}$, respectively, in a different cell line system. The consistent results suggested that the bromination indeed potentiated the inhibitory effect of the flavanones. (Table 1) [11]. 
Taken together, the dibromopinocembrin (TH011) and dibromopinostrobin (TH002) were selected for further cell-based and in vivo toxicity analysis.

TH002 and TH011 were both tested for cytotoxicities in LLC/MK2, THP-1, HEK, HepG2, and Huh-7 cell lines representing DENV common targets (Tables 1 and 2). Noted that LLC/MK2 and HEK cell lines were originated from renal epithelium of Macaca mulatta (rhesus monkey) and human embryo, respectively; whereas HepG2 and Huh-7 cell lines were originated from human hepatocellular carcinoma. Despite various performance, the cytotoxicities to all cell lines were $>50 \mu \mathrm{M}$, or at least 10 times higher than the efficacies of particular compounds $(2.06-5.83 \mu \mathrm{M})$. The original pinocembrin reduced endoplasmic reticulum stress and apoptosis by suppressing C/EBP homologous protein (CHOP), and caspase-3 expression/activity, respectively [32]. It is possible that the pinocembrin would interfere with DENV-induced ER stress, thereby reducing viral replication. Other positive-sense RNA viruses those replication involving ER-stress induction, such as Zika, Chikungunya, and enteroviruses, were also inhibited by pinocembrin [17]. Moreover, pinocembrin and pinostrobin were well known to downregulate pro-inflammatory cytokines (e.g., TNF- $\alpha$, IFN- $\gamma$, IL-6) in monocyte/macrophage, thus alleviated the burden of dengue immunopathogenesis. Likely, the halogenated derivatives would also target similar cellular pathways as their parent compounds.

Moreover, in vivo toxicity showed that TH002-induced hepatotoxicity was observed by ALT elevation on day 1 and 3. The liver enzyme returned to normal level on day 8 (Figure 2a) suggesting a self-limited and total recovery of the liver. The elevated ALT was not obviously seen in TH011 and DMSO control group. Note that both of the compounds were intravenously administered at $10 \mathrm{mg} / \mathrm{kg}$, or about 100 times of the $\mathrm{EC}_{50} \mathrm{~s}$. Therefore, the administered dose was intended to exceed a therapeutic level in blood circulation. After intravenous administration, pinocembrin was rapidly cleared from the circulation with a half-life of 12-14 min. in the rat (10 $\mathrm{mg}$, single dose) and $47 \mathrm{~min}$. in human (20 mg, iv drip) [32], mainly by CYP2A6 and CYP2A13 metabolism [19] and renal clearance. Therefore, further in vivo efficacy should include the multiple doses of administration in order to maintain the therapeutic level during viremia or febrile phase. Moreover, glycosidation of flavanone [33] and flavone [34] potentiated the antiviral efficacies resulting from increasing bioavailability and intestinal absorption [33,35]. The addition of carbohydrate moiety to the compounds could also be an option for further structural modification.

Our previous finding was dibromo- and diiodochrysins (5,7-dihydroxyflavones) potentiated the DENV1-4 inhibition, as well as a broad-spectrum inhibition to Zika viruses [9]. In this work, the halogenated flavanones similarly potentiated the DENV2 inhibition (NGC and 16681) in two cell line systems (Tables 1 and 2). Although the definitive molecular targets are still unknown, the compounds mainly inhibited at post-infection (Figure 3), similar to the parent compound, pinocembrin, and Zika virus at $17.4 \mu \mathrm{M}$ [17]. Another report suggested that pinocembrin inhibited at DENV NS3 protease activity ( $\mathrm{IC}_{50} 286.90 \mu \mathrm{g} / \mathrm{mL}$ ) [14], but not inhibit DENV NS5 polymerase activity [21]. Similarly, pinostrobin also inhibited DENV NS3 at the $\mathrm{IC}_{50}$ of $90.48 \mu \mathrm{g} / \mathrm{mL}$ ) [14], or the Ki of $345 \pm 70 \mu \mathrm{M}$ [24]). Other flavanones, such as 6-methylpinostrobin inhibited DENV2 and $4\left(\mathrm{EC}_{50 \mathrm{~s}} 15.99 \pm 5.38\right.$ and $11.70 \pm 6.04 \mu \mathrm{M}$, respectively), by interfering with conformational change of DENV envelope proteins during fusion [11]. Therefore, we included dengue envelope (E), protease (NS2B-3 pro), methyltransferase (NS5 MTase), and RNA-dependent RNA polymerase (NS5-pol) to molecular docking panel (Figure 4). Results showed that the most likely target of TH011 and TH002 was NS5 MTase for the strongest binding affinities $(-9.0 \mathrm{kcal} / \mathrm{mol})$ as compared to the parent compounds $(-8.3$ and $-8.1 \mathrm{kcal} / \mathrm{mol})$ and the inhibitor, sinefungin $(-8.9 \mathrm{kcal} / \mathrm{mol})$. The second possible target was NS5-pol, whereas E and NS2B-3 pro were unlikely for their moderate affinity contribution. The results were then confirmed by MD simulation (Figure 5). G83 was a key residue interacting with the $\mathrm{Br}^{6}$ atom of dibrominated flavanones. Note that the viral MTase activities were critical to the replication of positive-sense RNA viruses in the cytoplasmic compartment, whereby the host MTases were unavailable. Additionally, the eukaryotic ribosomal system is tightly stringent over the methylated capped species (cap 1, N7 and 2'-O methylation) for mRNA translation. Therefore, 
the in vitro N7 and 2'-O NS5 methyltransferase assays mimicking both of methylation activities could be used for further investigation [36].

\section{Materials and Methods}

\subsection{Compound Synthesis}

\subsubsection{General Procedure for Bromination}

A $30 \%$ aqueous solution of $\mathrm{H}_{2} \mathrm{O}_{2}$ (3.0 eq.) was added to the flask of flavanone $(0.1 \mathrm{mmol})$ and $\mathrm{NaBr}$ (3.0 eq.) in $\mathrm{CH}_{3} \mathrm{COOH}(2.5 \mathrm{~mL})$; then, the mixture was stirred at room temperature for $24 \mathrm{~h}$. The reaction was monitored by TLC. At the endpoint, the crude was treated with $\mathrm{Na}_{2} \mathrm{~S}_{2} \mathrm{O}_{3}$ and extracted with EtOAc $(3 \times 10 \mathrm{~mL})$. The reunited organic fractions were dried over anhydrous $\mathrm{Na}_{2} \mathrm{SO}_{4}$; after filtration, the solvent was evaporated under reduced pressure. Final products were isolated and then purified by chromatographic column while using hexane: EtOAc: acetone $=60: 40: 4$ as eluent.

\subsubsection{General Procedure for Iodination}

The starting materials were isolated from Boesenbergia rotunda (L.) Mansf. (Zingiberaceae). They are enantiomerically pure by nature. A $30 \%$ aqueous solution of $\mathrm{H}_{2} \mathrm{O}_{2}$ (3.0 equiv.) was added to the flask of flavanone $(0.1 \mathrm{mmol})$ and $\mathrm{KI}\left(3.0\right.$ equiv.) in $\mathrm{CH}_{3} \mathrm{COOH}(2.5 \mathrm{~mL})$; then, the mixture was stirred at room temperature for $24 \mathrm{~h}$. The reaction was monitored by TLC. At the end, the crude was treated with $\mathrm{Na}_{2} \mathrm{~S}_{2} \mathrm{O}_{3}$ and extracted with EtOAc $(3 \times 10 \mathrm{~mL})$. The separated organic fractions were dried over anhydrous $\mathrm{Na}_{2} \mathrm{SO}_{4}$; after filtration, the solvent was evaporated under reduced pressure. The final products were purified by chromatographic column using hexane: EtOAc: acetone $=60: 40: 4$ as eluent.

\subsubsection{Identification by Mass Spectrometry, ${ }^{1} \mathrm{H}$ and ${ }^{13} \mathrm{C}-\mathrm{NMR}$}

All of the NMR spectra $\left({ }^{1} \mathrm{H}\right.$ and $\left.{ }^{13} \mathrm{C}-\mathrm{NMR}\right)$ were recorded in deuterated chloroform $\left(\mathrm{CDCl}_{3}\right)$, acetone- $d_{6}$, methanol- $d_{4}$ (MeOD) or dimethylsulfoxide- $d_{6}$ (DMSO- $d_{6}$ ) on a Bruker AV400 and Varain Mercury 400 plus spectrometer at $400 \mathrm{MHz}$ for ${ }^{1} \mathrm{H}-\mathrm{NMR}$ and at $100 \mathrm{MHz}$ for ${ }^{13} \mathrm{C}-\mathrm{NMR}$. The chemical shifts $(\delta)$ are assigned in comparison with residual solvent protons. The mass spectra were recorded by High Resolution ESI-QTOF Mass Spectrometer.

6,8-dibromo-5,7-dihydroxyflavanone (TH011): light brown powder (93\% yield). ${ }^{1} \mathrm{H}-\mathrm{NMR}\left(\mathrm{CDCl}_{3}\right) \delta 12.74$ (s, 1H), $7.45(\mathrm{~m}, 5 \mathrm{H}), 6.67(\mathrm{bs}, 1 \mathrm{H}), 5.58(\mathrm{dd}, J=12.2,3.5 \mathrm{~Hz}, 1 \mathrm{H}), 3.15(\mathrm{dd}, J=17.3,12.2 \mathrm{~Hz}, 1 \mathrm{H}), 3.00$ $(\mathrm{dd}, J=17.3,3.5 \mathrm{~Hz}, 1 \mathrm{H}) ;{ }^{13} \mathrm{C}-\mathrm{NMR}\left(\mathrm{CDCl}_{3}\right) \delta 195.7,159.3,158.0,157.4,137.5,129.1,126.0,103.9,90.6$, 89.0, 79.7, 42.6; HR-ESI-MS $m / z$ calcd. for $\mathrm{C}_{15} \mathrm{H}_{9} \mathrm{Br}_{2} \mathrm{O}_{4} \mathrm{Na}$ [M $\left.+2 \mathrm{Na}-\mathrm{H}\right]^{+} 456.8663$, found 456.8657 .

6,8-dibromo-5-hydroxy-7-methoxyflavanone (TH002): yellow powder (96\% yield). ${ }^{1} \mathrm{H}$-NMR $\left(\mathrm{CDCl}_{3}\right) \delta$ $12.61(\mathrm{~s}, 1 \mathrm{H}), 7.48(\mathrm{~m}, 5 \mathrm{H}), 5.61(\mathrm{dd}, J=12.3,3.4 \mathrm{~Hz}, 1 \mathrm{H}), 3.98(\mathrm{~s}, 3 \mathrm{H}), 3.18(\mathrm{dd}, J=17.3,12.3 \mathrm{~Hz}, 1 \mathrm{H}), 3.05$ $(\mathrm{dd}, J=17.3,3.4 \mathrm{~Hz}, 1 \mathrm{H}) ;{ }^{13} \mathrm{C}-\mathrm{NMR}\left(\mathrm{CDCl}_{3}\right) \delta 196.3,162.1,159.0,157.7,137.1,128.8,125.7,105.9,98.3$, 96.6, 79.2, 60.7, 42.4; HR-ESI-MS $\mathrm{m} / z$ calcd. for $\mathrm{C}_{16} \mathrm{H}_{12} \mathrm{Br}_{2} \mathrm{O}_{4} \mathrm{Na}[\mathrm{M}+\mathrm{Na}]^{+} 448.90000$, found 448.89938. 6,8-diiodo-5-hydroxy-7-methoxyflavanone (TH012): light green crystal (73\% yield). ${ }^{1} \mathrm{H}-\mathrm{NMR}$ (acetone- $d_{6}$ ) $\delta 13.02(\mathrm{~s}, 1 \mathrm{H}), 7.47(\mathrm{~m}, 5 \mathrm{H}), 5.85(\mathrm{dd}, J=12.6,3.2 \mathrm{~Hz}, 1 \mathrm{H}), 3.91(\mathrm{~s}, 3 \mathrm{H}), 3.37(\mathrm{dd}, J=17.3,12.6 \mathrm{~Hz}, 1 \mathrm{H})$, $3.14(\mathrm{dd}, J=17.3,3.2 \mathrm{~Hz}, 1 \mathrm{H}){ }^{13} \mathrm{C}-\mathrm{NMR}$ (acetone- $\left.d_{6}\right) \delta 198.2,167.6,164.0,163.0,139.2,129.6,127.1$, 106.4, 95.61, 94.7, 80.5, 61.2, 42.6; HR-ESI-MS $m / z$ calcd. for $\mathrm{C}_{16} \mathrm{H}_{11} \mathrm{I}_{2} \mathrm{O}_{4} \mathrm{Na}[\mathrm{M}+2 \mathrm{Na}-\mathrm{H}]^{+} 566.8542$, found 566.8525 .

6-iodo-5-hydroxy-7-methoxyflavanone (TH018): yellow oil (10\% yield). ${ }^{1} \mathrm{H}-\mathrm{NMR}$ (acetone- $d_{6}$ ) $\delta 12.95$ (s, $1 \mathrm{H}), 7.53(\mathrm{~m}, 5 \mathrm{H}), 6.33(\mathrm{~s}, 1 \mathrm{H}), 5.68(\mathrm{dd}, J=13.0,3.1 \mathrm{~Hz}, 1 \mathrm{H}), 3.98(\mathrm{~s}, 3 \mathrm{H}), 3.29(\mathrm{dd}, J=17.4,13.0 \mathrm{~Hz}$, $1 \mathrm{H}), 2.92(\mathrm{dd}, J=17.4,3.1 \mathrm{~Hz}, 1 \mathrm{H}) .{ }^{13} \mathrm{C}-\mathrm{NMR}$ (acetone- $\left.d_{6}\right) \delta 195.3,165.6,164.8,163.6,162.2,137.8,129.0$, $128.9,126.1,103.2,93.2,91.9,79.4,66.0,42.6$. 


\subsection{Antiviral Cell-Based Study}

\subsubsection{Cells and Viruses}

LLC/MK2 (ATCC ${ }^{\circledR}$, Manassas, VA, USA CCL-7), HEK-293 (ATCC ${ }^{\circledR}$ CRL-1573), HepG2 (ATCC ${ }^{\circledR}$ HB-8065), THP-1 (ATCC ${ }^{\circledR}$ TIB-202), and C6/36 (ATCC ${ }^{\circledR}$ CRL-1660) cell lines were propagated and maintained as previously described $([9,11,37]$. Huh-7 cells were maintained in DMEM (Gibco ${ }^{\circledR}$, Langley, OK, USA) supplemented with $10 \%$ fetal bovine serum at $37{ }^{\circ} \mathrm{C}$ under $5 \% \mathrm{CO}_{2}$. Reference DENV2 strains New Guinea C strain (NGC) and 16,681 were propagated in C6/36 cells, as described $[9,11]$.

\subsubsection{Cytotoxic Concentration $\left(\mathrm{CC}_{50}\right)$ Test}

LLC/MK2, THP-1, HEK-293, HepG2, or Huh-7 cells were seeded at $10^{4}$ cells per well of 96-well plate and incubated overnight. Compounds were prepared to 6-10 different concentrations in filter-sterilized dimethylsulfoxide (Merck ${ }^{\circledR}$, Darmstadt, Germany) before addition to the cells. The plates were incubated for $48 \mathrm{~h}$ before the MTS reagent (Promega ${ }^{\circledR}$, Madison, WI, USA) was added to cells according to the manufacturer's protocol and incubated for $4 \mathrm{~h}$ before analysis by spectrophotometry at $A_{450 \mathrm{~nm}}$. Huh-7 cytotoxicity was assessed by the Alamar Blue assay (Invitrogen ${ }^{\circledR}$, Waltham, MA, USA) and read by fluorometry at the excitation and emission wavelengths at 570 and $600 \mathrm{~nm}$, respectively [38]. Each compound was tested in triplicate. Cytotoxic concentrations $\left(\mathrm{CC}_{50}\right)$ were calculated while using non-linear regression analysis and the results were reported as means and standard deviation of three independent experiments.

\subsubsection{Effective Concentration $\left(\mathrm{EC}_{50}\right)$ Test}

LLC/MK2 were seeded at $5 \times 10^{4}$ cells per well of 24-well plate in growth medium and incubated overnight at $37^{\circ} \mathrm{C}$ under $5 \% \mathrm{CO}_{2}$. Cells were infected with DENV2 NGC at the multiplicity of infection (MOI) of 0.1 for $1 \mathrm{~h}$ with gentle rocking every $15 \mathrm{~min}$. Cells were washed with PBS and incubated with MEM supplemented with $1 \%$ fetal bovine serum, $100 \mathrm{I} . \mathrm{U} . / \mathrm{mL}$ penicillin, and $100 \mu \mathrm{g} / \mathrm{mL}$ streptomycin. The compound was added to the virus-infected cells during and after infection. The cells were incubated for $72 \mathrm{~h}$, unless otherwise indicated, at $37{ }^{\circ} \mathrm{C}$ under $5 \% \mathrm{CO}_{2}$. Supernatants were collected and the viral infectivity was analyzed by $96-$-well plaque titration [39]. Data were plotted and the $\mathrm{EC}_{50}$ values were calculated by nonlinear regression analysis. Each concentration was tested in duplicate and the results were reported as the means and standard deviation of three independent experiments. The selectivity index was calculated from the ratio of $\mathrm{CC}_{50}$ and $\mathrm{EC}_{50}$. Moreover, additional EC50s of TH002 and TH011 were also taken from Huh-7 $\left(8 \times 10^{4}\right.$ cells) and DENV2 16,681 (MOI of 1). Supernatants were collected after $72 \mathrm{~h}$ incubation for plaque titration $\mathrm{EC}_{50}$ values were calculated by nonlinear regression analysis. Data were presented by means and standard errors of three independent experiments.

\subsubsection{Attachment Inhibition Study}

Huh-7 were seeded at $8 \times 10^{4}$ cells per well of 24 -well plate in DMEM supplemented with $10 \%$ FBS and incubated overnight at $37^{\circ} \mathrm{C}$ under $5 \% \mathrm{CO}_{2}$. The cells were infected with the DENV2 16,681 at the MOI of 1 for $1 \mathrm{~h}$ at $37^{\circ} \mathrm{C}$. Compounds were diluted in DMSO and pre-incubated with the virus at $37^{\circ} \mathrm{C}$ for $1 \mathrm{~h}$, or added to the infected cells during or after the infection. The cells were washed with PBS and then incubated with DMEM supplemented with $2 \%$ fetal bovine serum for $72 \mathrm{~h}$ at $37^{\circ} \mathrm{C}$ under $5 \% \mathrm{CO}_{2}$. DMSO was used as a mock treatment. Supernatants were collected and the viral infectivity was analyzed by plaque titration. Three independent experiments were performed in order to verify the results. 


\subsubsection{Fusion Inhibition Study}

C6/36 were seeded at $1 \times 10^{5}$ cells per well of 24 -well plate MEM that was supplemented with $10 \% \mathrm{FBS}$ and incubated overnight at $28^{\circ} \mathrm{C}$. Cells were infected with the virus at the multiplicity of infection (MOI) of 1 for $1 \mathrm{~h}$ at $28^{\circ} \mathrm{C}$. Compounds TH002 and TH011 were diluted in DMSO and added to the infected cells to the final concentration of $10 \mu \mathrm{M}$ in $1 \%$ DMSO after DENV2 NGC (M.O.I. of 1) infection. Cells were incubated with MEM supplemented with $1 \%$ fetal bovine serum for $48 \mathrm{~h}$ before the addition of $0.5 \mathrm{M}$ MES. Cells were incubated for an additional $24-48 \mathrm{~h}$ at $28^{\circ} \mathrm{C}$ until the fused cells were visualized under light microscope.

\subsection{Animal Toxicity Study}

The animal care and use protocol identification number 016-2562 was approved by the Institutional Animal Care and Use Committee (CU-ACUP) of the Faculty of Medicine, Chulalongkorn University, Bangkok, Thailand, based on the National Institutes of Health, USA's criteria for the use and treatment of laboratory animals. Male 8-week-old C57BL/6 mice purchased from the National Laboratory Animal Center, Nakhornpathom, Thailand were used in the experiments.

TH011 and TH002 were diluted with 10\% DMSO in normal saline solution. The preparations were intravenously administered at the concentration of $10 \mathrm{mg} / \mathrm{kg}$ through a tail vein ( $n=5 /$ group). The $10 \%$ DMSO in normal saline solution was used as vehicle control. Blood were collected through tail vein nicking at day one, three, and eight after administration and the serum samples were kept at $-80{ }^{\circ} \mathrm{C}$ until analysis. Renal function (serum creatinine; Scr) and liver function (serum alanine transaminase; ALT) were measured by colorimetric assays while using QuantiChromTM (DICT-500, BioAssay, Hayward, CA, USA) and EnzyChrom (EALT-100, BioAssay), respectively.

\subsection{Computational Studies}

\subsubsection{Molecular Docking}

The crystal structures of all four interested DENV proteins were downloaded from the protein databank (PDB), including E protein (1OKE), NS2B/3 protease (2FOM), NS5 MTase (5EHI), and Pol domain (3VWS). The three-dimensional (3D) structures of all flavanones and reported inhibitors were constructed using GaussView 6 program and they were optimized at the B3LYP/6-31G* basis set [27] using Gaussian 16 software [40]. Each flavanone was docked with 100 independent runs into the four targets using AutoDock VinaXB [23] and compared with the known inhibitor in order to predict the binding pattern and affinity. The docking grid dimension; $20 \times 20 \times 20=8000 \AA^{3}$ were set as the previously reported binding sites for each protein target [27]. The $\mathrm{x}, \mathrm{y}$, and $\mathrm{z}$ coordinates of each grid box are listed in Table S1 (in Supplementary Materials). Results were illustrated in the heatmap diagram. UCSF Chimera program [41] was used for visualization. The binding orientation of the compound with the highest binding affinity was selected as the initial structure for performing molecular dynamics (MD) simulation.

\subsubsection{Molecular Dynamics Simulation and FMO-RIMP2/C-PCM Calculation}

The complex structures resulted from the molecular docking study were simulated for 300-ns under the periodic boundary condition (PBC) with the isothermal-isobaric (NPT) scheme while using the AMBER 16 program. The system preparation, minimization, and MD simulation at $300 \mathrm{~K}$ were set as previously described [42]. Protein was treated by AMBER ff14SB forcefield [43]. The partial charge of each ligand was prepared following the standard protocol [44], while the other parameters were taken from the general AMBER force field [45]. The 100 snapshots that were extracted from the last $100 \mathrm{~ns}$ were chosen to calculate the binding free energy using the MM/GBSA method [46]. From this set, the representative model of the potent flavanones taken from the clustering method based on pairwise best-fit root-mean-square deviations (RMSDs) of ligand and the residues within $5 \AA$ around the ligand was further studied by the FMO-RIMP2/C-PCM method [47] while using the GAMESS 
program [48]. The intermolecular interaction energy (Pair interaction energy; PIEDA) is given by the sum of contributed energies; electrostatic $\left(E_{E S}\right)$, charge exchange $\left(E_{E X}\right)$, charge transfer $\left(E_{C T+M I X}\right)$, dispersion $\left(E_{D I}\right)$, and the solvation effect $\left(\Delta G_{S o l}^{C-P C M}\right)[43,49]$

\section{Conclusions}

This is the first report of newly synthesized dibromopinocembrin and dibromopinostrobin as potential leads of dengue inhibitors with good antiviral efficacies, mild toxicities in multiple cell lines, and animal model. The proposed molecular target was the viral methyltransferase with the G83 residue binding to ${ }^{6} \mathrm{Br}$ atom of the compounds.

\section{Patents}

This work is under preparation for Thailand patent submission.

Supplementary Materials: The following are available online Table S1: The grid box parameters for molecular docking using AutoDock VinaXB, Figure S1: NMR spectra of TH011, Figure S2: NMR spectra of TH002, Figure S3: NMR spectra of TH012, Figure S4: NMR spectra of TH018, Figure S5: Fusion inhibition assay treated by TH002 and TH011, Figure S6: Solubility comparison of pinocembrin (TH022) and chrysin.

Author Contributions: Conceptualization, S.B. and W.C.; methodology, S.B., T.S., P.V., K.H., T.N.T.H.; software, Y.S., T.R.; animal experiments, S.B., P.V., A.L.; compound synthesis and identification, T.N.T.H., W.C.; computational study, K.H., Y.S., T.R.; cell-based investigation, S.B., T.S., J.J.H.C.; writing—original draft preparation, S.B.; writing-review and editing, S.B., T.R., W.C.; supervision, W.C.; project administration, S.B.; funding acquisition, S.B., T.R., W.C. All authors have read and agreed to the published version of the manuscript.

Funding: This research was funded by National Research Council of Thailand and Health Systems Research Institute (HSRI), grant number 62-090 and Ratchadapisek sompotch endowment fund, Faculty of Medicine, Chulalongkorn University, grant number MF-3/62. The APC was partially funded by Chulalongkorn University and MDPI. The work was partially funded by AMED project Grant No. 19ae0101047h0002.

Acknowledgments: Reference dengue viruses were gifts from Padet Siriyasatien, Faculty of Medicine, Chulalongkorn University. HepG2, HEK-293, and THP-1 cells were gifted from Nattiya Hirankarn, Parvapan Bhattarakosol, Tanapat Palaga, Chulalongkorn University. The computational resources were provided by JCPHCI/OakforestPaCS through the HPCI System Research Project (Project ID: hp200156).

Conflicts of Interest: The authors declare no conflict of interest.

\section{References}

1. World Health Organization (WHO). Dengue and Severe Dengue. 2020. Available online: https://www.who. $\mathrm{int} /$ news-room/fact-sheets/detail/dengue-and-severe-dengue (accessed on 25 June 2020).

2. St. John, A.L. Influence of Mast Cells on Dengue Protective Immunity and Immune Pathology. PLoS Pathog. 2013, 9, e1003783. [CrossRef]

3. Thomas, L.; Verlaeten, O.; Cabié, A.; Kaidomar, S.; Moravie, V.; Martial, J.; Najioullah, F.; Plumelle, Y.; Fonteau, C.; Dussart, P.; et al. Influence of the dengue serotype, previous dengue infection, and plasma viral load on clinical presentation and outcome during a dengue-2 and dengue-4 co-epidemic. Am. J. Trop. Med. Hyg. 2008, 78, 990-998. [CrossRef]

4. Hidari, K.I.P.J.; Suzuki, T. Dengue virus receptor. Trop. Med. Health 2011, 39, 37-43. [CrossRef]

5. Acosta, E.G.; Castilla, V.; Damonte, E.B. Functional entry of dengue virus into Aedes albopictus mosquito cells is dependent on clathrin-mediated endocytosis. J. Gen. Virol. 2008, 89, 474-484. [CrossRef]

6. Zaitseva, E.; Yang, S.-T.; Melikov, K.; Pourmal, S.; Chernomordik, L.V. Dengue Virus Ensures Its Fusion in Late Endosomes Using Compartment-Specific Lipids. PLoS Pathog. 2010, 6, e1001131. [CrossRef]

7. Welsch, S.; Miller, S.; Romero-Brey, I.; Merz, A.; Bleck, C.K.; Walther, P.; Fuller, S.D.; Antony, C.; Krijnse-Locker, J.; Bartenschlager, R. Composition and three-dimensional architecture of the dengue virus replication and assembly sites. Cell Host Microbe 2009, 5, 365-375. [CrossRef]

8. Fischl, W.; Bartenschlager, R. Exploitation of cellular pathways by Dengue virus. Curr. Opin. Microbiol. 2011, 14, 470-475. [CrossRef] 
9. Suroengrit, A.; Yuttithamnon, W.; Srivarangkul, P.; Pankaew, S.; Kingkaew, K.; Chavasiri, W.; Boonyasuppayakorn, S. Halogenated Chrysins Inhibit Dengue and Zika Virus Infectivity. Sci. Rep. 2017, 7, 13696. [CrossRef]

10. Frabasile, S.; Koishi, A.C.; Kuczera, D.; Silveira, G.F.; Verri, W.A., Jr.; Duarte Dos Santos, C.N.; Bordignon, J. The citrus flavanone naringenin impairs dengue virus replication in human cells. Sci. Rep. 2017, 7, 41864. [CrossRef]

11. Srivarangkul, P.; Yuttithamnon, W.; Suroengrit, A.; Pankaew, S.; Hengphasatporn, K.; Rungrotmongkol, T.; Phuwapraisirisan, P.; Ruxrungtham, K.; Boonyasuppayakorn, S. A novel flavanone derivative inhibits dengue virus fusion and infectivity. Antivir. Res. 2018, 151, 27-38. [CrossRef]

12. Cataneo, A.H.D.; Kuczera, D.; Koishi, A.C.; Zanluca, C.; Silveira, G.F.; Arruda, T.B.; Suzukawa, A.A.; Bortot, L.O.; Dias-Baruffi, M.; Verri, W.A., Jr.; et al. The citrus flavonoid naringenin impairs the in vitro infection of human cells by Zika virus. Sci. Rep. 2019, 9, 16348. [CrossRef]

13. Kiat, T.S.; Pippen, R.; Yusof, R.; Ibrahim, H.; Khalid, N.; Rahman, N.A. Inhibitory activity of cyclohexenyl chalcone derivatives and flavonoids of fingerroot, Boesenbergia rotunda (L.), towards dengue-2 virus NS3 protease. Bioorganic Med. Chem. Lett. 2006, 16, 3337-3340. [CrossRef]

14. Othman, R.; Kiat, T.S.; Khalid, N.; Yusof, R.; Newhouse, E.I.; Newhouse, J.S.; Alam, M.; Rahman, N.A. Docking of noncompetitive inhibitors into dengue virus type 2 protease: understanding the interactions with allosteric binding sites. J. Chem. Inf. Modeling 2008, 48, 1582-1591. [CrossRef]

15. Bernini, R.; Pasqualetti, M.; Provenzano, G.; Tempesta, S. Ecofriendly synthesis of halogenated flavonoids and evaluation of their antifungal activity. New J. Chem. 2015, 39, 2980-2987. [CrossRef]

16. Teixeira, R.R.; Pereira, W.L.; Oliveira, A.F.; da Silva, A.M.; de Oliveira, A.S.; da Silva, M.L.; da Silva, C.C.; de Paula, S.O. Natural products as source of potential dengue antivirals. Molecules (Basel Switzerland) 2014, 19, 8151-8176. [CrossRef]

17. Lee, J.L.; Loe, M.W.C.; Lee, R.C.H.; Chu, J.J.H. Antiviral activity of pinocembrin against Zika virus replication. Antivir. Res. 2019, 167, 13-24. [CrossRef]

18. Gonzales, G.B.; Smagghe, G.; Grootaert, C.; Zotti, M.; Raes, K.; Van Camp, J. Flavonoid interactions during digestion, absorption, distribution and metabolism: a sequential structure-activity/property relationship-based approach in the study of bioavailability and bioactivity. Drug Metab. Rev. 2015, 47, 175-190. [CrossRef] [PubMed]

19. Kakimoto, K.; Murayama, N.; Takenaka, S.; Nagayoshi, H.; Lim, Y.R.; Kim, V.; Kim, D.; Yamazaki, H.; Komori, M.; Guengerich, F.P.; et al. Cytochrome P450 2A6 and other human P450 enzymes in the oxidation of flavone and flavanone. Xenobiotica Fate Foreign Compd. Biol. Syst. 2019, 49, 131-142. [CrossRef]

20. Manach, C.; Morand, C.; Gil-Izquierdo, A.; Bouteloup-Demange, C.; Rémésy, C. Bioavailability in humans of the flavanones hesperidin and narirutin after the ingestion of two doses of orange juice. Eur. J. Clin. Nutr. 2003, 57, 235-242. [CrossRef] [PubMed]

21. Allard, P.M.; Dau, E.T.; Eydoux, C.; Guillemot, J.C.; Dumontet, V.; Poullain, C.; Canard, B.; Guéritte, F.; Litaudon, M. Alkylated flavanones from the bark of Cryptocarya chartacea as dengue virus NS5 polymerase inhibitors. J. Nat. Prod. 2011, 74, 2446-2453. [CrossRef]

22. Hengphasatporn, K.; Plaimas, K.; Suratanee, A.; Wongsriphisant, P.; Yang, J.M.; Shigeta, Y.; Chavasiri, W.; Boonyasuppayakorn, S.; Rungrotmongkol, T. Target Identification Using Homopharma and Network-Based Methods for Predicting Compounds Against Dengue Virus-Infected Cells. Molecules (Basel Switzerland) 2020, 25, 1883. [CrossRef]

23. Koebel, M.R.; Schmadeke, G.; Posner, R.G.; Sirimulla, S. AutoDock VinaXB: implementation of XBSF, new empirical halogen bond scoring function, into AutoDock Vina. J. Cheminform. 2016, 8, 27. [CrossRef]

24. Heh, C.H.; Othman, R.; Buckle, M.J.; Sharifuddin, Y.; Yusof, R.; Rahman, N.A. Rational discovery of dengue type 2 non-competitive inhibitors. Chem. Biol. Drug Des. 2013, 82, 1-11. [CrossRef]

25. Yao, Y.; Huo, T.; Lin, Y.L.; Nie, S.; Wu, F.; Hua, Y.; Wu, J.; Kneubehl, A.R.; Vogt, M.B.; Rico-Hesse, R.; et al. Discovery, X-ray Crystallography and Antiviral Activity of Allosteric Inhibitors of Flavivirus NS2B-NS3 Protease. J. Am. Chem. Soc. 2019, 141, 6832-6836. [CrossRef]

26. Noble, C.G.; Lim, S.P.; Chen, Y.L.; Liew, C.W.; Yap, L.; Lescar, J.; Shi, P.Y. Conformational flexibility of the Dengue virus RNA-dependent RNA polymerase revealed by a complex with an inhibitor. J. Virol. 2013, 87, 5291-5295. [CrossRef] 
27. Lafreniere, M.A.; Desrochers, G.F.; Mekbib, K.; Pezacki, J.P. An affinity-based probe for methyltransferase enzymes based on sinefungin. Can. J. Chem. 2017, 95, 1059-1063. [CrossRef]

28. Cassidy, A.; Kay, C. Phytochemicals: Classification and Occurrence. In Encyclopedia of Human Nutrition (Third Edition); Caballero, B., Ed.; Academic Press: Waltham, MA, USA, 2013; pp. 39-46. [CrossRef]

29. Asakura, H.; Kitahora, T. Chapter 23 - Antioxidants and Polyphenols in Inflammatory Bowel Disease: Ulcerative Colitis and Crohn Disease. In Polyphenols: Prevention and Treatment of Human Disease, 2nd ed.; Watson, R.R., Preedy, V.R., Zibadi, S., Eds.; Academic Press: Cambridge, MA, USA, 2018; pp. 279-292. [CrossRef]

30. Mahalanobish, S.; Saha, S.; Dutta, S.; Ghosh, S.; Sil, P.C. Chapter 3 - Anti-inflammatory efficacy of some potentially bioactive natural products against rheumatoid arthritis. In Discovery and Development of Anti-Inflammatory Agents from Natural Products; Brahmachari, G., Ed.; Elsevier: Amsterdam, The Netherlands, 2019; pp. 61-100. [CrossRef]

31. Zhao, Q.; Zhang, Y.; Wang, G.; Hill, L.; Weng, J.-K.; Chen, X.-Y.; Xue, H.; Martin, C. A specialized flavone biosynthetic pathway has evolved in the medicinal plant, Scutellaria baicalensis. Sci. Adv. 2016, 2, e1501780. [CrossRef]

32. Lan, X.; Wang, W.; Li, Q.; Wang, J. The Natural Flavonoid Pinocembrin: Molecular Targets and Potential Therapeutic Applications. Mol. Neurobiol. 2016, 53, 1794-1801. [CrossRef]

33. Nascimento, A.C.; Valente, L.M.M.; Gomes, M.; Barboza, R.S.; Wolff, T.; Neris, R.L.S.; Figueiredo, C.M.; Assunção-Miranda, I. Antiviral activity of Faramea bahiensis leaves on dengue virus type-2 and characterization of a new antiviral flavanone glycoside. Phytochem. Lett. 2017, 19, 220-225. [CrossRef]

34. Barboza, R.S.; Valente, L.M.M.; Wolff, T.; Assunção-Miranda, I.; Neris, R.L.S.; Guimarães-Andrade, I.P.; Gomes, M. Antiviral Activity of Faramea hyacinthina and Faramea truncata Leaves on Dengue Virus Type-2 and Their Major Compounds. Chem. Biodivers. 2018, 15. [CrossRef]

35. Hollman, P.C.H. Absorption, Bioavailability, and Metabolism of Flavonoids. Pharm. Biol. 2004, 42, 74-83. [CrossRef]

36. Boonyasuppayakorn, S.; Padmanabhan, R. Construction of plasmid, bacterial expression, purification, and assay of dengue virus type 2 NS5 methyltransferase. Methods Mol. Biol. (Clifton N. J.) 2014, 1138, 361-373. [CrossRef]

37. Phumee, A.; Chompoosri, J.; Intayot, P.; Boonserm, R.; Boonyasuppayakorn, S.; Buathong, R.; Thavara, U.; Tawatsin, A.; Joyjinda, Y.; Wacharapluesadee, S.; et al. Vertical transmission of Zika virus in Culex quinquefasciatus Say and Aedes aegypti (L.) mosquitoes. Sci. Rep. 2019, 9, 5257. [CrossRef] [PubMed]

38. Lee, J.K.; Chui, J.L.M.; Lee, R.C.H.; Kong, H.Y.; Chin, W.X.; Chu, J.J.H. Antiviral activity of ST081006 against the dengue virus. Antivir. Res. 2019, 171, 104589. [CrossRef] [PubMed]

39. Boonyasuppayakorn, S.; Suroengrit, A.; Srivarangkul, P.; Yuttithamnon, W.; Pankaew, S.; Saelee, T.; Prompetchara, E.; Salakij, S.; Bhattarakosol, P. Simplified dengue virus microwell plaque assay using an automated quantification program. J. Virol. Methods 2016, 237, 25-31. [CrossRef]

40. Frisch, M.J.; Trucks, G.W.; Schlegel, H.B.; Scuseria, G.E.; Robb, M.A.; Cheeseman, J.R.; Scalmani, G.; Barone, V.; Petersson, G.A.; Nakatsuji, H.; et al. Gaussian 16 Rev. C.01; REV: Wallingford, CT, USA, 2016.

41. Pettersen, E.F.; Goddard, T.D.; Huang, C.C.; Couch, G.S.; Greenblatt, D.M.; Meng, E.C.; Ferrin, T.E. UCSF Chimera-a visualization system for exploratory research and analysis. J. Comput. Chem. 2004, 25, 1605-1612. [CrossRef]

42. Hengphasatporn, K.; Garon, A.; Wolschann, P.; Langer, T.; Yasuteru, S.; Huynh, T.N.T.; Chavasiri, W.; Saelee, T.; Boonyasuppayakorn, S.; Rungrotmongkol, T. Multiple Virtual Screening Strategies for the Discovery of Novel Compounds Active Against Dengue Virus: A Hit Identification Study. Sci. Pharm. 2020, 88. [CrossRef]

43. Wang, J.; Wolf, R.M.; Caldwell, J.W.; Kollman, P.A.; Case, D.A. Development and testing of a general amber force field. J. Comput. Chem. 2004, 25, 1157-1174. [CrossRef]

44. Hengphasatporn, K.; Kungwan, N.; Rungrotmongkol, T. Binding pattern and susceptibility of epigallocatechin gallate against envelope protein homodimer of Zika virus: A molecular dynamics study. J. Mol. Liq. 2019, 274, 140-147. [CrossRef]

45. Duan, Y.; Wu, C.; Chowdhury, S.; Lee, M.C.; Xiong, G.; Zhang, W.; Yang, R.; Cieplak, P.; Luo, R.; Lee, T.; et al. A point-charge force field for molecular mechanics simulations of proteins based on condensed-phase quantum mechanical calculations. J. Comput. Chem. 2003, 24, 1999-2012. [CrossRef] 
46. Nutho, B.; Mahalapbutr, P.; Hengphasatporn, K.; Pattaranggoon, N.C.; Simanon, N.; Shigeta, Y.; Hannongbua, S.; Rungrotmongkol, T. Why Are Lopinavir and Ritonavir Effective against the Newly Emerged Coronavirus 2019? Atomistic Insights into the Inhibitory Mechanisms. Biochemistry 2020. [CrossRef] [PubMed]

47. Tokiwa, T.; Nakano, S.; Yamamoto, Y.; Ishikawa, T.; Ito, S.; Sladek, V.; Fukuzawa, K.; Mochizuki, Y.; Tokiwa, H.; Misaizu, F.; et al. Development of an Analysis Toolkit, AnalysisFMO, to Visualize Interaction Energies Generated by Fragment Molecular Orbital Calculations. J. Chem. Inf. Model. 2019, 59, 25-30. [CrossRef] [PubMed]

48. Fedorov, D.G. The fragment molecular orbital method: theoretical development, implementation in GAMESS, and applications. Wiley Interdiscip. Rev. Comput. Mol. Sci. 2017, 7, e1322. [CrossRef]

49. Kitaura, K.; Sugiki, S.-I.; Nakano, T.; Komeiji, Y.; Uebayasi, M. Fragment molecular orbital method: analytical energy gradients. Chem. Phys. Lett. 2001, 336, 163-170. [CrossRef]

Sample Availability: Samples of the compounds TH022, TH019 are available from the authors.

(C) 2020 by the authors. Licensee MDPI, Basel, Switzerland. This article is an open access article distributed under the terms and conditions of the Creative Commons Attribution (CC BY) license (http://creativecommons.org/licenses/by/4.0/). 